\title{
Sejarah Pemikiran Islam
}

\section{"Merkantilisme"}

\author{
Ainan Radiyah
}

\section{Ainanradiyah51806@gmail.com}

Salah satu permasalahan beberapa Negara berkembang adalah Efek dari kemiskinan yang selalu berdampak negatif terhadap struktur sosial suatu negara. Pencurian di mana-mana, belum lagi kasusu porstitusi yang semakin merebak baik di kota, maupun pedesaan. (Sirajuddin, 2016). Hal ini pun pernah terjadi pada masa Ekonomi pra klasik di zaman monarki di eropa, yang mana paham ekonomi pada saat itu di sebut mercantilisme. Paham merkantilisme ini muncul dab berkembang mulai abad 1500 hingga abad 1800 (Qadariyah, 2018). Beberapa tokoh Merkantilisme yang terkena antara lain adalah Jean Bodin (1530-1596) Thornas Mun (15711641) Jean Baptis Colbert (1619-1683) Daavid Hurne (1711-1776) dan Sir William Petty (16231687) (Prabowo 2019).

Pemikiran Ekonomi Kalangan“ Merkantilis" atau Merkantilisme merupakan“ sesuatu teori ekonomi yang beranggapan bahwa kesejahteraansuatu negeri hanya di lihat oleh banyaknya peninggalan ataupun modal yang di miliki oleh negeri yang bersangkutan, serta banyaknya volume perdagangan global yaitu ekspor sangat berarti". Aset negara ataupun modal suatu negara bisa ditafsirkan dengan besarnya kapital atau modal negara ( mineral berharga, paling utama emas ataupun komoditas yang lain) yang dipunyai oleh negeri serta modal ini dapat diperbesar jumlahnya dengan tingkatkan ekspor serta menghindari( sebisanya) impor sehingga neraca perdagangan dengan negeri lain hendak senantiasa positif. Merkantilisme mengarahkan kalau pemerintahan sesuatu negeri wajib menggapai tujuan ini dengan melaksanakan proteksi terhadap perekonomiannya, dengan mendesak ekspor( dengan banyak insentif) serta kurangi impor( umumnya dengan pemberlakuan tarif yang besar).

Sistem ekonomi yang seperti inilah yang disebut dengan kebijakan ekonomi merkantilisme. Istilah "Merkantilisme" sendiri diambil dari kata Merchant yaitu "Pedagang". Menurut ideology in, jika Negara ingin maju, maka negara harus melaksanakan perdagangan internasional dengan Negara lain. Karena menurut para merkantilisme, sumber pendapatan 
Negara adalah dari perdagangan luar negeri dengan Negara lain, dengan Uang negara yang selalu surplus. Pada abad ke-16 sampai ke-18, banyak sekolah yang dominan mengajarkan paham ini. Peristiwa ini memicu, Tingginya intervensi suatu pemerintahan dalam sebuaj Negara yang mendorong lahirnya kapitalisme. Kebutuhan akan pasar bebas yang tidak di ajarkan oleh merkantilisme akhirnya menimbulkan banyak sekali kritik dan peperangan dengan kaum imperialis. Alhasil, Sistem merkantilisme ini lambat laun mulai menghilang di akhir abad ke-18, seiring dengan hadirnya teori baru yang di pelopori oleh Adam Smith dalam karyanya The Wealth of Nations, ketika Inggris menjadi Negara dengan industri terbesar dunia saat itu.

Merkantilis ialah model sistem ekonomi dengan intervensi penguasa yang dominan, proteksionisme dan politik colonial, diperuntukkan adanya pembagian kerja secara teknis dan pembagian kerja teritorial, yang kemudian akan meningkatkan perdagangan luar negeri. Sistem ini membuat kebijakan yang sangat menjaga industry dalam negeri tapi tetap menjujung tinggi persaingan, namun di batasi dengan kebijakan terkontrol dari penguasa yang mendorong kegiatan industry dengan upah rendah dalam negeri. Hal yang dilakukan paham merkantilisme ini untuk mencapai tujuannya yaitu : Pertama, melarang ekspr loham mulia seperti emas dan perak karena merupakan harta yang paling di sukai. Kedua, Negara harus memperbanyak ekspor dengan harga mahal ke Negara tetangga dan mengurangi impor yang tidak penting. Ketiga, dalam kebijakaan ekspor-impor, pemerintah menginginkan surplus yang sebanyak banyaknya. Keempat, memonopoli perdagangan agar dapat memelihara keabadian dan tunduk kepada para koloni. Kelima, menentang keras adanya bea, pajak, serta restriksi intern kepada mobilitas barang, Keenam, membangun pemerintahan pusat yang kuat, dan Ketujuh, mencapai pertumbuhan angka penduduk yang tinggi, namun harus disertai SDM yang tinggi juga agar dapat memenuhi pemasokan kepentingan militer dan pengelolaan administrasi merkentilis yang kuat dan hebat pula. Kebijakan ekonomi di sistem ini lebih bersifat makro, hal ini di karenakan untuk mencapai suatu tujuan yaitu meningkatkan proteksi industri, demi menjaga segala bentuk rencana perdagangan internasional yang menguntungkan. Tentunya hal ini perlu dilakukan jika dalam usaha ingin meningkatkan kemajuan negaranya di mata dunia perdagangan internasional dan perluasan kolonialisme.(Faruq \& Mulyanto, 2017) 


\section{Daftar Pustaka}

Prabowo, Gama. "Merkantilisme dan Dampaknya bagi Indonesia." kompas.com, 2019.

Faruq, U. Al, \& Mulyanto, E. (2017). Sejarah Teori-Teori Ekonomi (Issue 1).

Qadariyah, L. (2018). Buku Ajar Sejarah Pemikiran Ekonomi Islam (p. 235). https://books.google.co.id/books?id=dAz5DwAAQBAJ\&pg=PA20\&dq=kebijakan+fiskal+ pada+masa+rasulullah+dan+khulafaur+rasyidin\&hl=id\&sa=X\&ved=2ahUKEwjc_rXXp4ju AhV67XMBHV1JBxAQ6AEwAXoECAYQAg\#v=onepage\&q=kebijakan fiskal pada masa rasulullah dan khulafaur rasyidi

Sirajuddin. (2016). Konsep Pemikiran Ekonomi Islam. Laa Maysir, 3(1), 46-60. 